Article

\title{
Reassessing Religion and Politics in the Life of Jagjivan Rām
}

\section{Peter Friedlander ${ }^{(0)}$}

South and South East Asian Studies Program, School of Culture History and Language, College of Asia and the Pacific, Australian National University, Canberra, ACT 2600, Australia; peter.friedlander@anu.edu.au

Received: 13 March 2020; Accepted: 23 April 2020; Published: 1 May 2020

\begin{abstract}
Jagjivan Ram (1908-1986) was, for more than four decades, the leading figure from India's Dalit communities in the Indian National Congress party. In this paper, I argue that the relationship between religion and politics in Jagjivan Ram's career needs to be reassessed. This is because the common perception of him as a secular politician has overlooked the role that his religious beliefs played in forming his political views. Instead, I argue that his faith in a Dalit Hindu poet-saint called Ravidās was fundamental to his political career. Acknowledging the role that religion played in Jagjivan Ram's life also allows us to situate discussions of his life in the context of contemporary debates about religion and politics. Jeffrey Haynes has suggested that these often now focus on whether religion is a cause of conflict or a path to the peaceful resolution of conflict. In this paper, I examine Jagjivan Ram's political life and his belief in the Ravidāsī religious tradition. Through this, I argue that Jagjivan Ram's career shows how political and religious beliefs led to him favoring a non-confrontational approach to conflict resolution in order to promote Dalit rights.
\end{abstract}

Keywords: religion; politics; India; Congress Party; Jagjivan Ram; Ravidās; Ambedkar; Dalit studies; untouchable; temple building

\section{Introduction: Jagjivan Ram, Congress, and Ravidās}

Appleby (2006) has suggested that there are three ways in which religious leaders can be constructive builders of peace: first, by fostering the common good of the entire population; second, by their positions as key figures in a conflict; and third, by being repositories of local knowledge and custodians of culture. In this article, I suggest that Jagjivan Ram's career fully matched each of these criteria. His political career was prefaced on the notion that only by the economic and social uplift of the whole of Indian society could the struggle for Dalit liberation be realized. His birth as a Dalit and status as a Dalit leader made him an authentic voice for Dalits in the government, and his embodiment of traditional forms of Dalit spirituality meant that he was uniquely well qualified to be a voice for a distinctive Dalit spirituality's perspective on peaceful conflict resolution through spirituality and affirmative action.

However, a central question that needs to be considered in relation to Jagjivan Ram is the following: what role did religion play in his career as an Indian politician? This is particularly because in his public life, over four decades throughout the numerous portfolios he held in Congress governments from 1946 to 1977, he seems to have been careful to maintain a distance between his personal religious beliefs and his political role as a facilitator in the uplifting of all communities in India. However, there are some indications that support a view that alongside his political career, he also acted as a patron for Dalit communities and, in particular, for Ravidāsī religious traditions. In addition, all of these relate to his reverence for Ravidās as an embodiment of a distinctive Dalit religious identity within Hinduism. While public perceptions of Jagivan Ram as a politician normally focus on his role in secular society 
during the Nehruvian era, I shall explore here how his personal Ravidāsī religious beliefs impacted his political life throughout his career.

One important implication of this, I suggest, is that it showed the way that Jagjivan Ram was able to find a peaceful and non-confrontational way within the Hindu caste establishment to protest against discrimination against Dalits in India and work for their emancipation.

\section{Jagjivan Ram and the Śiv Nārāyaṇī Movement (1908-1928)}

In this section, I will explore the relationship between Jagjivan Ram's religious identity and his emerging political identity during his childhood and formative years.

Jagjivan Ram was born into a family from the camār (hereafter anglicized as Chamar) community, which was commonly seen by higher caste (savarna) Hindus as associated with leather working and agricultural laboring. These communities were often described in Hindi as achüt ("untouchable") or aspriśya, a Sanskrit form of the same word. However, after 1928, Jagjivan Ram started to also describe himself as a Dalit, a Hindi word often translated as "oppressed". Jagjivan Ram's own translation of the term was "depressed", as in the name of his organization the dalit vārg ligg, the depressed classes league. However, it is notable that he also continued to use all three terms in his writings and speeches throughout his life when addressing different audiences. For instance, when addressing parliament in Hindi in 1981 and criticizing Indira Gandhi, he spoke of how the Muslims and his own community were both achüt, untouchables (Ram 2005, p. 312). Whilst in 1980, in his book on challenging the caste structure in India, he wrote about how his community had become "Asparshya" when India had been invaded by the Aryans in antiquity (Ram 1980, p. 10). This shows how Jagjivan Ram modulated his message for different audiences; for his own community, he was a Dalit; for sympathetic higher caste audiences, he was aspriśya; and for audiences whose views he wanted to criticize, he could self-identify as ach $\bar{u} t$, an untouchable.

Jagjivan Ram's father, Shobhi Ram, had served in the military and learnt English while stationed at Multan in the Punjab. During his period of service in the Punjab, he had met followers of the lower caste Hindu reformist Śiv Nārāyaṇi tradition, which he then joined. It is of note that military service appears to have been one pathway through which some Dalits in nineteenth-century India were able to improve their status (Mendelsohn and Vicziany 1998, p. 88). Perhaps due to this, whilst Jagjivan Ram's family had been poor, they did own some land. Mendelsohn and Vicziany also noted that when they asked Jagjivan Ram about the discrimination that he experienced in his childhood, he said that in the village in Bihar where he grew up, it had been slightly less than that in some other areas. One instance of this, he told them, was that Chamars in his village had been allowed to draw water from wells in the common areas in the village (Mendelsohn and Vicziany 1998, p. 88).

For many, Chamars Ravidās (active circa 1450-1500) was regarded as a form of patron saint, as Ravidās was the most significant poet-saint, or sant (hereafter Sant), to have emerged from their community. The Hindi term Sant has a complex history but largely refers to followers of popular movements that developed from the fourteenth century onwards. This was led by Sants such as Nāmdev, a cotton printer from Maharashtra; Kabīr, a Muslim weaver from Varanasi; and Ravidās, a leather worker from Varanasi. There were also many women Sants, such as Sahajobāī and Dayābāī, who were from Rajasthani merchant communities. There were also some figures who are sometimes identified as Sants and sometimes as bhaktas ("devotees"), such as Mīrābāī from the Rajasthani kṣatriya community. The Sants emphasized reverence for the divine as a formless spirit equally present in all of humanity. Sants and bhaktas alike argued in favor of social equality and opposed any form of discrimination based on caste, class, gender, or religion.

Eleanor Zelliot and Rohini Mokashi-Punekar have argued that the untouchable Sants formed part of a movement whose characteristics included "acceptance of all castes and women into the fold of the saints", "a critical attitude towards orthodox religion", and the founding of "some sort of institution" (Zelliot and Mokashi-Punekar 2005, p. 14). Gail Omvedt has also argued that the development of anticaste intellectual movements in India from 1500 to 1750 emphasized "a strong form of devotional 
movement with a vision of equality, an emphasis on empirical thinking, and access to ecstasy for all." This was then followed by a phase during colonialism, up to around 1920, when "anticaste intellectuals had to form their own vision in confrontation with the developing 'Hindu nationalism' of the elite." (Omvedt 2008, p. 23). This would place the childhood and formative years of Jagjivan Ram in the era when the religious and political ideas of the Sant movements and their development during the colonial period were emerging onto the stage of Indian engagement with the freedom struggle.

Jagivan Ram's daughter, Meira Kumar, in her description of Jagjivan Ram's childhood, emphasized that despite growing up amidst poverty, discrimination, and repression, her father Jagiivan Ram constantly struggled to overcome the challenges in his life. She also noted that he had been deeply influenced by his father having been a priest of the Śiv Nārāyaṇi movement who spent his days writing out by hand copies of their sacred text anyās for use by followers of the tradition. Jagjivan Ram was a brilliant student and got the opportunity to go to the village school from the age of six and then on to middle and high school where he experienced discrimination. The discrimination included the provision of separate water supplies for Dalit students in schools. However, in an incident described in almost all accounts of his childhood, he would smash every pitcher of water set up for the use of only the Dalits each time it was set up and, by doing this, managed to persuade the school authorities to abandon this practice. She also gave an account of another incident from his childhood when he experienced discrimination on a family visit to a place called Khopira, where they owned some land. When they got to the village, they were asked to get down from the cart in which they were travelling, fold away their umbrellas, and walk through the neighborhood, as the local Brahmin community in that area maintained a traditional prohibition against Dalits riding in vehicles or using umbrellas (Kumar 2005, pp. 34-38).

Jagjivan Ram's father was a deeply religious person and a priest of the Siv Nārāyaṇi Sant movement. In order to understand Jagjivan Ram's life, it is vital to realize that this movement provided a model for both spiritual belief and social reconstruction, which contributed to the base on which Jagjivan Ram also modeled his own actions. Because of this, it is essential to gain some understanding of this movement's history and characteristics.

Perhaps the earliest external accounts of the movement can be found in Horace Hayman Wilson's account of the religious groups he encountered in India in around 1828. According to Wilson, the main characteristics of the Śiv Nārāyaṇis were that the community included Hindus, Muslims, Christians, and people from "the lower classes of the mixed population" (Wilson 1861, p. 358). Admission to the community was not through a guru but made by individuals joining a Siv Nārāyaṇi gathering, making offerings to a sacred text of the tradition, and listening to its teachings. The teachings stressed moral virtues including truth, temperance, and mercy, along with a prohibition on polygamy, and rather than having any special dress, the followers continued to observe the customs of the dress of Hindu and Muslim communities. The founder, Śiv Nārāyan, was a Rajput of the nerīvān lineage from Chandravan, a village near Ghazipur, and lived during the reign of Muhammad Shah (1702-1748). Wilson also noted that most of the Śiv Nārāyan̄is were Rajputs and many were soldiers (sipāhi), whilst others were bearers (porters) and were found mostly around Ghazipur and in Calcutta (Wilson 1861, pp. 358-59).

The next account of the Śiv Nārāyan̄is was prepared at the request of George Abraham Grierson (Grierson 1918). This was written by Babu Bajirangi Lal, who was on the municipal Board at Ghazipur, on the basis of enquiries he made from the Sant in charge of the local Śiv Nārāyaṇi monastery, or dham. He said that the practices of the Siv Nārāyan̄ī community were still as described by Wilson, and they had four main centers in the Ghazipur region. However, by 1918, they had also built temples in Cawnpore (Kanpur) and in Bombay (Mumbai), and Śiv Nārāyan̄īs were found in Calcutta, Karachi, Rangoon, and other places. He also noted that there were Christian converts in the community from the town of Shahabad (now in the state of Haryana). He further commented that despite many of the community having been Rajputs in the past, now most were Chamars, $d u s \bar{a} d h s$ (another untouchable community of landless agricultural workers) and other untouchable communities. 
Another account of the history, development, and characteristics of this movement was made by the Indian scholar Parasurām Caturvedī in his seminal work on the Sant traditions of Northern India, first published in 1952. There were several key points by which his account augmented what had previously been written.

First, he pointed to the continuities between earlier Sant religious practices, as advocated by Sants such as Ravidās and Kabīr, and those of Śiv Nārāyaṇ (1716-1790). These included teachings based on the sabda, the divine sound and control of the breath through prānāyanma. He also noted the importance of sacred texts in the tradition and how these were connected with earlier teachings through a lineage that linked Śiv Nārāyaṇ's guru, Dukhhāran ("remover of suffering"), a Kayastha caste member from Baliya, with his guru Malukdās (1573-1671), who was also a Kayastha from Allahabad. Śiv Nārāyaṇ was the author of numerous works and a tradition developed amongst each community, or samāj, of his followers to have as a central object of devotion a handwritten manuscript of one of his works, such as the guru anyās. Such texts also appear as a central feature of Jagjivan Ram's childhood, and the creation of an authoritative sacred text for Ravidās also appears to have been a focus of interest for Jagivan Ram.

Second, Caturvedī argued that on the basis of a study of Śiv Nārāyaṇ's works, one of the main goals of his teaching was described as being the attainment of a state of entry into a world called sant vilās or sant des ("Sant's delight" or "Sant land"). This is the ideal true homeland of the Sants, which exists in a realm beyond the mundane world, which is called the kāl des ("the land of death") in which humanity lives ensnared in karma and delusion. The path to this ideal land was to be found by each individual through self-realization and through the abandoning of forty forms of faults such as drinking alcohol. This is a particularly important point as the idea of the attainment of liberation within life is also a key concept, which Jagjivan Ram mentions in his writings on the teachings of Ravidās.

Third, a key feature of Śiv Nārāyaṇ's tradition was that it accepted followers from all backgrounds-Hindu, Muslim, and Christian —and did not discriminate against anyone based on caste or any other form of distinction and did not formally ask them to change any of their dress or customs or renounce their earlier religious affiliations. By the 1950s, only one-fifth of the movement was from high castes, and the majority were from jāti, such as "camār, dusādh and others who were considered untouchable" (Caturvedī 1972, p. 649). Women were also granted equal rights in the community and could, perhaps, he said, become heads of monasteries. The community also celebrated annual festivals on occasions such as the anniversaries of the birth, death, and enlightenment of Śiv Nārāyan and the completion of the sacred text the guru anyās. These features of the Śiv Nārāyaṇi movement were also shared with followers of the Ravidāsī tradition and appear to be closely aligned with Jagjivan Ram's own views on how people from different castes and communities could work together.

Fourth, a key feature of Śiv Nārāyan's followers was that they focused not just on the spiritual wellbeing of their community but also on education, organization, and lobbying for their wellbeing in the world. Where there were sufficient numbers of devotees, they organized themselves into an association (sangathan), and the members would be called "sant sipāh" $\bar{\imath}$ ("soldier Sants") and would elect an organizing committee, including a Mahant (priest), a Vazir (Minister), and other office holders. They would then raise funds, from which they would send a portion to a higher-level center of the movement, seeking registration, and then use the remaining funds for local community purposes (Caturvedī 1972, pp. 633-50). This aspect of the Śiv Nārāyaṇi movement also provided a model for the kind of political activities that Jagjivan Ram promoted through his establishment of Ravidās assemblies and the development of Ravidās temples as focuses for development of Dalit communities.

A more recent description of the role of the Śiv Nārāyanīs in the Dalit movements of Kanpur in the twentieth century is found in Bellwinkel-Schempp's work, where she described how their temple was an early center of Dalit activity in Kanpur. She also noted that whilst the movement had similarities to the Sikh movement, sometimes describing their sacred text as the Guru Granth, it was also very different, as it accepted aspects of the Vedic Hindu tradition and included many Tantric diagrams in its texts (Bellwinkel-Schempp 2007, p. 2178). 
From this account of the Śiv Nārāyaṇī movement, it can be seen that its program for spiritual and social reformation had numerous aspects that were similar to the path that Jagjivan Ram took in his own career.

The characteristic features of such movements included the following points: practices based on a spirituality that identified itself as a distinctive Sant tradition within Hinduism and the importance of authoritative sacred texts and temples. The ideas of the movement were also not solely spiritual but emphasized belief in the possibility that all of humanity could attain a home in an ideal world in which there was universal equality amongst all of those who followed the Sant teachings. The means for the attainment of this ideal state were based on the practice of a morality in which truth, non-violence, abstinence from intoxicants, and monogamy were key virtues. The movements also emphasised the creation of community through the celebration of annual festivals and building temples to foster the development of democratic representations of the community.

These descriptions of the changing characteristics of the Śiv Nārāyan̄i movement over time suggest that a change was taking place in Sant movements in the early twentieth century. After being primarily religious organizations in the eighteenth century, by the end of the nineteenth century, Sant traditions were transforming into organizations analogous to political movements. For Dalits such as Jagjivan Ram, they presented a model for how like-minded traditions could link together to build communities and to seek simultaneously the spiritual and social uplift of their communities in the world.

\section{Jagjivan Ram and Ravidās Sabhās and the Ravidās Jayantī (1928-1931)}

In this section, I will explore how, while Jagjivan Ram was a student, he deliberately linked his religious beliefs with his first steps into mass political activism.

Jagjivan Ram is often reported to have organized Ravidāsī sabhās (assemblies) in Calcutta from 1928 onwards and to have founded various organizations. Beltz noted that Jagjivan Ram founded the Ravidās General Assembly (Ravidās mahāsabhā) in 1928 (Beltz 2005, p. 100), whilst according to other authors, he also founded the All India Ravidās Assembly (akhil Bhārtiy Ravidās sabhā) in Calcutta in 1929 and then became the secretary of the All India Depressed classes league (akhil bhārtiy dalit vārg lig) by 1935 (Kumar 2013, p. 51). Jagjivan Ram's wife, Indrani Ram, wrote in her memoirs that while studying in Calcutta from 1928 to 1932, Jagjivan Ram had been actively organizing Ravidās sabhās and attempting to unite different Dalit groups around the figure of Ravidās. In addition, he also promoted the celebration of Ravidās jayantī processions ("Ravidās Anniversary celebrations") (Ram 2010, p. 49).

In a description of such an assembly, Nau Nihal Singh wrote that in 1928, Jagjivan Ram "organised Ravidas's Sabhas in the various localities of Calcutta and received a good response. Once a big meeting was held in the Wellington Park in Calcutta and some 15,000 Achuts had gathered. The 20-year-old reformer, himself a college student, was to the audience their ideal and saviour". Singh also noted that Jagjivan Ram spoke out against meat eating and drinking alcohol, as he saw the abandoning of these practices as a "pre-condition for the uplift of the untouchables" (Singh 1977, p. 37). This description of the assemblies suggests the possibility that Jagjivan Ram's initial work in this area was both an expression of his own Śiv Nārāyaṇi tradition and a development inspired by earlier caste assemblies by Dalit communities in Northern India.

The precise history of the holding of such assemblies $(s a b h \bar{a})$ and the related practice of anniversary (jayantī) celebrations is an area in which there is still much to be studied. The consensus appears to be that these forms of communal gatherings began, or perhaps took their present forms, only in the early twentieth century. Patel has argued that late-nineteenth-century higher caste assemblies served as models in Bihar for Dalit sabha assemblies, which began in 1913-1914. In these meetings, caste elders called for abstinence from drinking, the practice of monogamy, and avoiding killing animals by poisoning them and claimed Brahman status for Chamars (Patel 2017, pp. 65-66). Then, groups such as the $d u s \bar{a} d h$ communities began to hold general assemblies, mahāsabhä, every two years and began to claim that the $d u s \bar{a} d h$ s were not Dalits but actually a Kshatriya caste. 
Other Chamar leaders, such as Rāmcaran Kurīl, also began to organize Chamar Assemblies in locations such as Kanpur, where the first Ravidās Kurīl reform assembly (Ravidās Kurīl sudhār sabhā) was held in 1917. It should be noted that in descriptions of such assemblies written by Dalits themselves, they described them as not only aimed at reforming Dalits, as reported by authors writing about Jagjivan Ram's involvement in the assemblies, but also locations in which campaigns were developed against discriminatory high caste practices, such as bans on Dalits wearing jewelry or fine clothing (Dayāl 2006, p. 257). Kurīl then organized the second All India Ravidās General Assembly in Kanpur in 1935 and the fourth All India Ravidās General Assembly in Delhi in 1939 (Kurīl 1941, p. 6). Seen in this context, then, Jagjivan Ram's involvement in these assemblies should perhaps be seen as part of a broader movement at this time by Dalits in North India. However, what distinguishes Jagjivan Ram's actions is that, after he joined the Congress Party in 1931, he went on to set up the All India Depressed Classes League in Nagpur in 1935.

The beginnings of the practice of using processions honoring Ravidās jayantī, the anniversary of his birth and death in the Indian month of magh, as political demonstrations can be traced back to the first two decades of the twentieth century in Kanpur where the Ravidāsī leader Achutanand started the practice of taking out a public procession on the date of the Ravidās jayantī festival (Bellwinkel-Schempp 2007, p. 2178). This would suggest that Jagjivan Ram's efforts to promote the celebration of Ravidās jayanti in Calcutta in the 1920s were following an already existing model. The success of such actions was that they paved the way for the more widespread adoption of this practice across Northern India. When I was living in Varanasi in the 1980s, Ravidāsi community members also told me that the Ravidās jayantī celebrations had been a key way in which they claimed public space, as up to that time, caste Hindus in Varanasi had opposed Ravidāsīs gathering in public spaces in order to celebrate the Ravidās jayantī. Sangam Lal Pandey also mentioned in his work on Ravidās that he had attended such processions on Ravidās jayantī since 1954 in the Allahabad area, attended by thousands of Ravidāsīs (Pandey 1965, p. vii).

The role of Jagjivan Ram in encouraging the holding of Ravidāsī sabhās and the celebration of Ravidās Jayanti can be seen as an aspect of his political engagement that aligned with the trend of the era for mass mobilization. However, this is also another instance in which his own beliefs in relation to Ravidās and the precedents set by his Śiv Nārāyaṇī heritage clearly contributed to his vision for what he was doing. It is also notable that whilst his emphasis on morality and the abandoning of drinking appeared to suggest an alliance with the Arya Samaj's emphasis on uplifting the Dalits, his own Śiv Nārāyan̄ī heritage already included these as key virtues that needed to be taken up by Dalits to facilitate their uplifting in society.

\section{Jagjivan Ram's Opposition to Conversion and Congress (1931-1936)}

Jagivan Ram's religious beliefs and his opposition to conversion were also vital factors in a speech he made in 1931, which appears to have been a key reason why he then joined the Congress Party and its struggle for Indian Independence. This address was made at a convention of the Untouchability Society in Patna in 1931, at which Rajendra Prasad, a key figure in Congress, was the chief guest. In his speech, Jagjivan Ram stressed that the time for Dalits

to be preached at by caste Hindus to give up eating meat, abandon drinking alcohol and live pure lives, now won't work any longer. Now Dalits no longer wish to be given sermons, they demand to be treated properly, not just words, there is a need for concrete action. M. Ali Jinnah is demanding a separate country for Muslims and Dr. Ambedkar is agitating for arrangements for separate electoral zones. I am opposed to all forms of religious conversion. We are untouchable $(a c h \bar{u} t)$ Hindus. We are born Hindus, and will stay Hindus and die Hindus. We created the nation; we were not created by the nation. [my italics] The nation is ours ... We must alert society against religious conversion. We must abolish untouchability. In the battle for freedom every religion and jāti must join together in great numbers. (Saran 2017, p. 137) 
I argue that a close reading of this speech points to two important points in relation to Jagjivan Ram's religious beliefs. First, that his opposition to conversion was based on his faith in being a Hindu and a particular sort of Hindu, an untouchable Hindu. This suggests that this speech can be seen as having been an assertion of his faith in Ravidās and the teachings of the Sants.

Second, his belief that India was created by untouchable Hindus is a crucial point. This idea was a key feature of Dalit ideology in the twentieth century. Dalit leaders interpreted the then popular accounts of an Aryan invasion of India as accounts of how the Dalits were India's original inhabitants and that higher caste Hindus were descendants of foreign invaders who had settled in India.

It is important to note that the context for this opposition to conversion was not related to his later disagreements with Ambedkar. Rather, it sprang from opposition to conversion in a broader sense. In a different account of this speech, he was said to have also opposed specifically the conversion of Dalits to Islam, Christianity, and Buddhism, which would have reflected the experiences of Dalits at this time in Northern India who were the focus for conversion movements organized by many different religions.

After giving this speech, Jagjivan Ram went with Rajendra Prasad to Bombay in 1931, where he met Mahatma Gandhi, joined Congress's freedom struggle, and was given responsibility for Gandhi's Harijan Sevak Sangh ("Union for uplifting the untouchables") in Bihar (Maurya 2010, pp. 30-31).

\section{Re-Evaluating Jagjivan Ram and Bhim Rao Ambedkar (1936-1955)}

Almost all discussions of Jagjivan Ram's life include discussions of the significant differences in ideas between Jagiivan Ram and Bhim Rao Ambedkar (1891-1956), as both were, each in their own way, two of the most significant Dalit leaders in twentieth-century Indian politics. The key difference between them was that in 1936, Jagjivan Ram and Ambedkar parted company over their views on the role of religion in the Dalit struggle for rights. This arose because of Ambedkar's announcement at the Yeola Conference in 1935 that although he had been born a Hindu, he would not die a Hindu. He then made a number of speeches over the next few years explaining why he and his followers should renounce Hinduism, as within it there was no possibility of emancipation, and instead, they should adopt a new religion (Beltz 2005, pp. 50-58). However, Jagjivan Ram rejected Ambedkar's view and in public speeches said that even if Dalits converted to another religion, they would still suffer from the stigma of untouchability and risk alienating other Hindus (Nath 1987, p. 194). His widow, Indrani Jagjivan Ram also wrote about this issue in her biography and described how Ambedkar had tried to persuade Jagjivan Ram at the time to follow his lead. However, Jagjivan Ram argued with him that even when Dalits converted to other religions, such as Sikhism, they were still discriminated against within Sikhism and that converting was running away from the problem, and the only solution was a change that effected the whole of Indian society (Ram 2010, pp. 52-53). As previously argued in Section 4, Jagjivan Ram's views on conversion did not arise due to his disagreement with Ambedkar but were part of his fundamental religious beliefs.

Politically, the results of this conflict were that Ambedkar went on to found an independent political party, the Republican Party of India, and spent most of the rest of his life fighting for Dalit rights from outside of the political mainstream, whereas Jagjivan Ram became the most prominent Dalit leader within the Congress party and continued his struggle for Dalit liberation from within the ruling party for most of his life.

There has been considerable academic discussion of the contributions that Ambedkar and Jagivan Ram made to the Dalit movement. Jaffrelot even went so far as to write about Jagjivan Ram's contribution to Dalit movements in India under the heading "Stooge of Congress?" (Jaffrelot 2003, p. 97). His argument was that Jagjivan Ram's foundation of the Ravidās Mahāsabhā ("Ravidās general assembly") while he was studying in Calcutta in 1928 was part of a social reform effort based on Sanskritization, emulation of high caste Hinduism, rather than radical opposition to caste Hinduism as advocated by Ambedkar (Jaffrelot 2003, p. 98). He then highlighted the way that Jagjivan Ram had joined the Congress party in 1930 and adopted a Gandhian approach to challenging caste. Jaffrelot's 
proposition was that the Congress party attempted to use Jagjivan Ram as a counterweight to the growing strength of Ambedkar's more radical approach to challenging caste in India. In support of this, he suggested that the foundation of the All India Depressed Classes League during a Ravidās Mahāsabhā meeting in 1934 had inherent in its constitution a program of Sanskritization by untouchable Hindus rather than Ambedkar's basic program of challenging the very existence of the caste system. His conclusion was that Jagjivan Ram's advocacy of a Gandhian approach to Dalit uplift meant that, in the long run, his career in the Congress party did little to further the interests of Dalits within the Congress agenda and more broadly in India as a whole (Jaffrelot 2003, p. 102). Some authors have also suggested that his contribution to Dalit liberation was somewhat constrained by his role within the Congress party and that the longevity of his career was due to both "his competence and also his carefulness not to engage in dissent and controversy and that it was hard to estimate how much power he wielded within the Congress party over the years" (Mendelsohn and Vicziany 1998, pp. 207-8).

Against this, there are many other authors who have pointed to the positive contributions that Jagjivan Ram made to India through his political career, in particular as the Minister of Agriculture during 1967-1970 and as the Minister of Defense during the Indo-Pakistani war of 1971 during the struggle by Bangladesh for independence.

There are also some Dalit writers who have also made positive evaluations of Jagjivan Ram's contribution to the Dalit struggle in India. Notable amongst these are Sanjay Paswan and Pramanshi Jaideva, who included a substantial section on him in their Encyclopaedia of Dalits in India (2004). They situated him as having been a post Ambedkar Dalit leader and noted that Ambedkar had "once called him the champion of the Dalits" (Paswan and Jaideva 2004, p. 15). In the section of their chapter on Jagjivan Ram, under the heading "Dalits and Jagjivan Ram", they highlighted his work to set up structures to ensure minimum wages for all agricultural laborers, including Dalits from the 1930s to the 1950s (Paswan and Jaideva 2004, pp. 82-87). They then pointed out in a section on "Babu Jagjivan Ram as the Champion of the Dalits" that his contributions as Railway Minister led to the starting of the Indian Railways food services in which Dalits, were, for the first time, able to eat with higher caste people all over India. In addition his foundation of the Dalit Varga Sangh ("Depressed Classes Union") was a significant step towards the economic uplift of the Dalits (Paswan and Jaideva 2004, p. 88). In a section on "Jagjivan Ram, the man", they pointed to how he was praised for his hard work and skillful handling of parliamentary work (Paswan and Jaideva 2004, pp. 89-91).

They then turned to the relationship between his support for Hinduism and his political achievements. The crux of the issue, as they saw it, was that he was a theist and "many of his friends were not able to reconcile themselves to his blind faith and devotion to Rama" (Paswan and Jaideva 2004, p. 92). They singled out, in particular, that his faith in the story of Ram was not shaken by its anti-Shudra elements and that "[r] ecitation of quatrains and couplets from the Ramcharitmanas formed an essential part of Jagjivan Ram's daily routine" (Paswan and Jaideva 2004, p. 93).

It is striking that for these Ambedkarite writers, there was no doubt that his Hinduism was very much part of his identity, but that it was for them a problem, as it conflicted with Ambedkar's rejection of Hinduism. However, they reconciled the two positions by arguing that he said that Rām treated all alike and cited a famous passage in which Rām spoke with a bhīlinni, a tribal woman, due to which he said that "Rama treats all his devotees, whether high-born or low born alike as He told to Bhilini" (Paswan and Jaideva 2004, p. 92). The importance of the Rāmcaritmānas in lower caste Bihari religious practices in the nineteenth century is also clear from the critical role it played in the Hinduism of the bonded laborers who left India in the nineteenth century to work in Mauritius and Fiji.

They also noted the relationship of the Sants to Hinduism and mentioned how Kabīr, Nāmdev, and Ravidās were "neither kings, nor members of a high caste, still the world holds them in great veneration" (Paswan and Jaideva 2004, p. 91) and that there was "a striking affinity between Kabir's creed and Jagjivan Ram's ideology" (Paswan and Jaideva 2004, p. 94). 
This work is an important link to ways in which some modern Ambedkarite followers now reconcile Jagjivan Ram's and Ambedkar's ideas and see Jagjivan Ram as having been both a significant political leader and a follower of a distinctive Sant form of Hinduism.

It is also of note that many Dalit and Chamar groups also regarded Jagjivan Ram as a kind of patron for their activities. Johannes Beltz noted in a description of the Chambhars (Chamars) of Maharashtra that whilst the Mahār community regarded Ambedkar as their patron, the Chambhars regarded Ravidās and Jagjivan Ram as their leaders and wanted to continue to assert their Hindu and Chamar identity (Beltz 2005, pp. 98-100).

I would argue that Jagjivan Ram's disagreement with Ambedkar over the issue of conversion was not the result of his acceptance of caste Hindu ideology, but derived from his own Śiv Nārāyan̄i and Sant heritage. In particular, it is important not to conflate his particular vision of Dalit Hinduism with the views of higher caste Hindus. Seen in this light, he was not arguing that Dalits should accept caste Hindu views on what constitutes Hinduism, but, rather, he held to a desire to maintain beliefs inherited from his Śiv Nārāyañī and Sant heritage.

In particular, his public espousal of the idea that Dalit uplift would only be possible as part of universal uplift seems to echo Śiv Nārāyanī beliefs that real change could only come about when all Hindus accepted the validity of the Sant teachings of universal equality.

\section{EEàstri and Pāṇ̣ey's Sant Ravidās aur unkā kāvya (1956)}

Eāstri and Pāṇ̣ey's Sant Ravidās aur unkā kāoya (Sant Ravidās and his poetry) was the earliest serious modern Hindi academic study of Ravidās's life and works. It contained a study of the teachings of Ravidās and his life and works and included a pioneering attempt to edit a critical text of his verses based on manuscript sources. Jagjivan Ram wrote a preface to this volume, in which he started by explaining his views on the origins of the teaching of the Sants and stressed the difference between their teachings and those of what he saw as a "distorted", khalmal, orthodox Hindutva.

There is no unanimity amongst academics about the origin and development of the Sant movement. However, it is universally acknowledged that their works express the consciousness of the masses. In them there was a demand for a new social reformation, and a call for natural equality and a constant appeal for leadership which was not based on separation and discrimination, but on the ideal of unity. These teachings fanned the embers of awakening and while some were slowly extinguished others continued to burn bright and cast their light abroad. But no flame leapt up which could burn away all of the foulness of Hindutva. (Śāstri and Pāndẹey 1956, p. i)

It is notable that he is clearly distinguishing here between what he saw as true Hinduism, that of the followers of the Sants, and a distorted (khalmal) Hinduism as propagated by the supporters of Hindutva. The word khalmal is not common in Hindi but occurs several times in one of Jagjivan Rām's favorite works, Tulsīdās's Rāmcaritmānas. In this, the adjective khalmal is used when describing a mentality that is distorted and polluted as in a verse where somebody is cursed to become a snake with a distorted and polluted mentality (sarpa hohī khalmal mati byāpī, Tulsīdās 1968, p. 1061).

The term Hindutva had been coined by Vinayak Damodar Savarkar in a pamphlet in 1923 to mean a particular view of Hindutva "Hindu-ness" (Savarkar 1923). This corresponded with his political and religious agenda, which favored a redefinition of India as an ethnic Hindu state in which primacy was given to the authority of caste Hindu traditions and interpretations of Hinduism. This then became the guiding principle for many of the right-wing Hindu fundamentalist movements, which came to form the rạstrinya svayamsevaka sangha, the National Volunteer League, which is most commonly known as the RSS. Jagjivan Ram's rejection of Hindutva and its ideology is clear from the way that he speaks of it as khalmal, defiled or distorted, Hinduism, which suggests that he saw supporters of these organizations and supporters of Sant movements as fundamentally at odds with each other's teachings. 
Jagjivan Ram argued that the teachings of the Sants were also expressions of fundamental truths that were compatible with those found in orthodox Hindu sources, such as the Upanisads and Vedas, but not derived from them. Furthermore, he then said that it was regrettable that no authentic work on Ravidās had been compiled before this volume and expressed delight that "for the first time in centuries the authors have rectified this shortcoming" (Śāstri and Pāndẹ 1956, p. ii). He concluded by expressing his support for the need to universally acknowledge the debt that not only "Ravidāsi brothers" but all of humanity owes to Ravidās:

I want to say a few words about the natural connection which exists between Ravidāsī brothers and this great man. It is not just Ravidāsīs, who should revere Mahatma Ravidās, he should be revered by all of humanity. He attained that state beyond where caste and nationality etc. can reach and he attained that which lies beyond all such base sentiments. To keep alive the memory of Ravidās is not just the duty of Ravidāsīs, it is the responsibility of all of India's inhabitants. The present generation's orientation towards Sant literature is a sign of the thought-revolution we can see manifesting before our eyes and the expression of the success of this is leading to the foundation of a new society in which for the first-time mankind will attain liberation.-Minister for Communications, Indian Government, New Delhi-Jagjivan Ram

As if to also emphasize that he is writing not just as a private individual but as a representative of the Indian state, he also included his official title in his signature to this preface. It is also notable that whilst such clear expressions by Jagjivan Ram of his respect for Ravidās are not as well known as his parliamentary career, it is clear that when he did make them, their import was evidently considerable, as they showed that even from within the government, there was support for the followers of Ravidās.

It is also striking that his support for the idea of creating an authoritative text for Ravidās aligned well with his Śiv Nārāyaṇi respect for sacred texts as a key element in religious traditions. Jagjivan Ram's introduction to this pioneering attempt to create an authoritative version of the works of Ravidās highlighted his continuing public support for the Ravidāsī tradition. It indicates that between 1928, when he was promoting Ravidās sabhās, and 1956, when he wrote the introduction to this book, he continued to strongly support the teachings of Ravidās. This highlights the way in which, although the normative depiction of Jagjivan Ram in most accounts of his parliamentary career does not mention the religious values he inherited from his family's reverence for Sant traditions, they still continued to function as the fundamental ground on which he situated his political career.

\section{Jagjivan Ram and the Tughlaqabad Temple in Delhi in 1959}

A series of events in 2019 also pointed out the importance that Jagjivan Ram's endorsement of Ravidāsī activities had in the 1950s and, perhaps, how the impact of a lack of a similar voice today has changed the situation for Dalits and Ravidāsīs in modern India. The key issues here relate to a Ravidās temple, which was outside the Tughlaqabad Fort in Delhi and which had been established there by the early nineteenth century but was demolished by the Delhi Development Authority (DDA) in 2019.

An article in the Indian Journal The Caravan, gave a good account of how the temple had come to be built. Rishi Pal, the president of the managing committee of the temple in 2019, described how his ancestor Roopanand, in around 1830, had built a hut by a pond outside of the Tughlaqabad Fort. He then started to perform public religious rituals at the site, which was associated with two Ravidāsī oral traditions about the pond: first, that it had healing waters that could cure leprosy and second, that it was the site where Ravidās had given teachings to Sikandar Lodhi, the Sultan of Delhi, in the fifteenth century, who had then granted the land to Ravidās and his followers. There were also memorials to Roopanand and three successive temple priests at the pond, and part of a temple at the site was probably constructed in around 1905, on the basis of the bricks dating from 1905 used in the construction of the temple. After independence, the local Dalit community in the area restored the temple and, on 10 February 1959, they sent a letter inviting Jagjivan Ram to inaugurate the new 
temple, which he did on 1 March 1959. In 1960, the site was registered in their possession (Sagar 2019). However, 26 years later, in 1986, the year of Jagjivan Ram's death, the DDA began disputing their possession of the land. This was then followed by three decades of legal disputes, which ultimately led to a supreme court ruling against the temple committee and the temple's demolition on 10 August 2019.

The story of the Tughlaqabad Ravidās temple points to the way that Jagjivan Ram was able to support Chamar and Ravidāsī activities during his lifetime. His inauguration of the Tughlaqabad Temple had been part of a process of its legitimization during his lifetime. However, the changing circumstances in India, and perhaps the lack of strong Dalit voices in the ruling parties of India by the twenty-first century, eventually led to the demolition of this historic temple.

\section{Jagjivan Ram in the Ravidās Memorial Movement (1976-1986)}

Jagjivan Ram played a key role as a supporter and coordinator of the movement to build a Ravidās temple at Rajghat in Varanasi from 1976 until his death in 1986. One of the leading figures in this movement was Rāmlakhan (note that many Dalits do not use a surname, which is often a form of caste title in India). He was a former Uttar Pradesh Agriculture and Irrigation Minister, who took a leading role in the organization of this project. In an article in Ravidās, the magazine of the Ravidās Memorial Society, he described the project as being carried out under the support and direction (sahyog aur samraksan) of Jagjivan Ram and having been intended to provide a venue in central Varanasi in honor of Ravidās, as opposed to the temple to Ravidās at Seergovardhanpur to the South of the city (Rāmlakhan 1986a, p. 68). In a separate pamphlet about the project, he also described in detail how the land had been bought and registered in 1976 in the name of the "Ravidās Memorial Society" (ravidās smārak sosaițī) in Delhi and how Jagjivan Ram had laid the foundation stone on 12 April 1979 at a ceremony during a conference of the All India Ravidās General Assembly (akhil bhārtiy ravidās mahā-sammelan) (Rāmlakhan 1986b, p. 5). In personal communications to me when I visited the temple at that time in 1986, Rāmlakhan also told me that Jagjivan Ram had been the main donor who purchased the land for the temple and facilitated its purchase (Rāmlakhan, personal communication, 1986).

The context for this development was in part related to the political developments of the era. Although Jagjivan Ram had been a supporter of Indira Gandhi from when she came to power, he did not approve of her declaration of an emergency in 1975. This led to his resignation from the Congress party in 1977, demanding that she cancel the emergency and restore democracy. It was in this era of uncertainty that he also apparently started his involvement in this project to build a Ravidās temple in Varanasi. A further factor in this may have been that, as he was no longer concerned about his position in the Congress Party, he was finally able to begin to move away from abstaining from actions that did not support his public persona as a secular politician and act in ways that were more in accord with his reverence for Ravidās.

\section{Jagjivan Ram's Caste Challenge in India (1980)}

In addition to his public support for a Ravidās memorial project from 1976 to 1986, during this period, he also wrote a book called Caste Challenge in India (Ram 1980). In this book, he put together a carefully constructed discourse, aimed at non-Dalit readers, which set out his understanding of how caste discrimination arose and how it should be challenged.

He started from the standpoint that there was a tendency in all cultures for the development of inequality. However, he argued that when the Aryans entered India, they had only three castes, Brahmins, Kshatriyas, and Vaishyas, but after they clashed with the aboriginal inhabitants, the Shudras and those excluded from society came into being and became the "Asparshyas or the panchama" (the untouchables or the "fifth"). This system was then codified by the Brahmans and people were conditioned by belief in karma and rebirth to accept the new system. There were, however, revolts against this system, and the Buddha attempted to reform it, but did not succeed. Then, later reform movements fought against this system led by saints, such as "Ramananda, Kabir, Ravidas (Raidas), Eknath, Tukaram, Chaitanya, Nanak and many others", and all of them "sought to reform the people 
of the country and inculcate in them a new belief in the equality of all men before God." However, these movements did not fully succeed, as they were transformed into sects within society, rather than reforming society as a whole (Ram 1980, pp. 10-14).

The main chapters in the book carefully examine the issues facing India due to discrimination on the basis of caste. However, it is notable that his vision of a casteless society is ultimately based on a vision of an egalitarian society where all have equal economic abilities, and in order to achieve this, there will be a need for a three-pronged attack upon the caste system, based on legislation, economic development, and reservations for downtrodden members of society. It is only in this way, he argued, that prejudice against the formerly downtrodden members of society would be forgotten, and "we shall not only succeed in creating a new social and economic life in this country, but also in giving a decent burial to a system which has defied the endeavors of saints and savants from Lord Buddha to Mahatma Gandhi" (Ram 1980, p. 67). Key to understanding this book's message is that, unlike Ambedkar's rejection of Hinduism, Jagjivan Ram presented in this work his own approach to challenging caste in India, which preserved the diversity of Hindu religious traditions that was central to Jagjivan Ram's spirituality.

\section{Jagjivan Ram's Ravidās as a Symbol of Identity (1986)}

In 1986, the year that he passed away, Jagjivan Ram presented a much more radical public presentation of his ideas on the importance of Ravidās than he had in 1980. This was a Hindi language article in the magazine Ravidās called "Guru Ravidās as a symbol of identity for the embodiment of the divine" (Ram 1986). The term I have translated here as "embodiment of the divine" is in Hindi iśvar ke amśsharom, literally "embodiments of a portion of God". The idea that all living beings are equal embodiments of a portion of God is central to Ravidās's teachings and is found in a Ravidās verse in the Sikh sacred text, the Śrī Guru Granth, where Ravidās said that "Ravidās teaches to all, the divine is equally present in all" (sam dal samjhavai kou, see Callewaert 1996, p. 93). This is a key teaching, as it implies that the divine is equally present in all, from the highest caste Brahmin to the lowest castes, such as Chamars.

In this article, Jagjivan Ram laid out much more clearly than in his 1980 English language publication, his vision of the historical relationship between spirituality and social inequality. His basic position was that the desire for equality was present in all world societies, but that in India, the Aryan invasion had replaced the values of the original inhabitants of India with those of the Brahmins and their caste system. He then described the teachings of the original Indians as forms of tantra. It should be noted that his use of the term tantra here was not intended to be derogatory, as some modern Indians see the term, but was being used in the way it is sometimes used to describe the Sant teachings, as mentioned in relation to Śiv Nārāyaṇī sacred texts by Bellwinkel-Schempp (2007). Moreover, he does not appear to have been using this term to suggest any shortcomings in the original teachings of the aboriginal $(m \bar{u} l$ niv $\bar{a} s \bar{\imath})$ inhabitants of India but, rather, using tantra as a term to describe the inner spiritual practices of the Sants, such as sabda yoga and their views on the fundamental equality of all people.

However, Jagjivan Ram's message has been, on some occasions, misunderstood. This can be seen from a Government of India publication by Om Prakash Maurya translated into English by Rupali Kishore, which contains a translation of part of Jagjivan Ram's 1986 article. However, the translation completely alters the meaning of what Jagjivan Ram wrote. In particular, perhaps due to the translation process, the notion that the religious system of the aboriginal inhabitants of India was a form of tantra is transformed into Jagjivan Ram writing that the aboriginal inhabitants of India had been followers of "black magic" (Maurya 2010, p. 193). This mistranslation points to a larger problem; when considering the political career of Jagjivan Ram, some Hindu authors conflate Jagjivan Ram's faith in Ravidāsī and Śiv Nārāyan̄i Sant traditions with the beliefs of followers of orthodox high caste Hindutva Hinduism. This means that public perceptions of the role of religion in Jagiivan Ram's life run the risk of conflating 
Jagjivan Ram's own spirituality based on the Sant tradition with forms of Hindutva ideology that he specifically rejected in his 1956 preface to Śāstri and Pāṇdey (1956) work on Ravidās.

Reporting of his spirituality also often conflated his reverence for the Hindi work the Rāmcaritmānas with the Sanskrit epic the Rāmāyana. For instance, his long-time associate Nau Nihal Singh, who was Deputy Secretary of Indian Council of Scientific and Industrial Research, described Jagivan Ram as a vaiṣnava sagunopasaka (a worshipper of forms of Viṣnu with attributes) whose daily religious practices included recitations from Tulsīdās's Rāmcaritmānas (Singh 1977, pp. 11-12). He also mentioned that, like Kabīr, he "condemned the evils that have crept into Hinduism" and he "follows the dictates of a small voice even if they run contrary to the commandments of the "Shastras'"' (Singh 1977, p. 13). He also pointed out that he would quote verses by Kabir "who was a favorite of his father" (Singh 1977, p. 108). This appears to have been an account of his spirituality that retained an accurate description of how his practices reflected Sant spirituality.

In contrast, Triloki Nath Chaturvedi who was Governor of Karnataka in 2005, when speaking about Jagjivan's religious life, said “Ramayana was a great favourite. When Ramayana Paath, took place at his house on Sundays, he would read out to the gathering the meaning of each verse in the epic" (Chaturvedi 2005, p. 55). This seems to conflate his Sant spirituality with a perception of him as an orthodox Hindu.

In his 1986 article, Jagjivan Ram then developed his argument in more detail about how from the moment that the caste system had been introduced into India, opposition to it from the Dalits had also begun, in particular, in the medieval period, led by Sants from all corners of India. The Sants rejected the roots of the caste system and argued in favor of a liberal egalitarian religion that was different from that espoused by the false and empty forms of caste Hinduism that had infected India. Central to this struggle, he suggested, was that Ravidās, a Chamar, had taken on the proponents of caste Hinduism in their central fortress, the city of Varanasi. Key to this struggle, Jagjivan Ram argued, was the centrality in Ravidās's teachings of a denial of there being any different castes; instead, Jagivan Ram said Ravidās proclaimed that we were all of the same flesh and blood, and rather than belonging to different castes, such as Brahmin, Kshatriya, Vaishya, and Shudra, all humanity belonged to only one caste. Jagjivan Ram also argued that this was a core teaching of Sants, such as Ravidās, and Sants who had Muslim backgrounds, such as Kabīr, and that both Kabīr and Ravidās alike had argued for Hindu Muslim equality and unity. He then cited a number of verses by Ravidās and his contemporaries, which witnessed to the truth of what he was arguing.

The sources of these verses which he quoted were not given, and mostly they do not match with any particular textual tradition that I can identify. From various features of the Hindi language in them, such as the inclusion of modern forms of some words, it also appears possible that they were, in some cases, drawn from contemporary oral traditions. His argument could perhaps be read as meaning that Jagivan Ram's own views were also the views of Ravidās. My translation of some of the core of this article dealing with caste discrimination is as follows. Jagjivan Ram began by citing verses from Kabīr, Ravidās, and Nāmdev, which argued against discrimination by jāti, caste, or birth:

Ravidās, did not directly attack [the institution of caste] or like Kabīr say.

‘When did you become a Brahmin, when did we become Shudras?

When did we become blood, you become milk?

If Brahmins are born different,

Why aren't you born from a different way?'

Ravidās said.

'Don't ask what caste a man is born in, what is jāti or community (jāti kā pat)?

O Ravidās! All sons are sons of God, none is high or low born.' 
And.

'All alike are tangled up in the deception of caste and community, all of humanity has been afflicted by the disease of $j \bar{a} t i$.

O Ravidās! Don't ask about jāti, what is jāti or community.

Brahmin, Kshatriya, Vaishya or Shudra, all are only one jāti.'

Kabīr also spoke about this.

'Only one breath, only one essence, only one flame in existence.

All beings are made from only one substance, by only one Creator.'

Ravidās said.

'There are $j \bar{a} t i s$ in jātis,

like leaves within leaves in a banana plant.

O Ravidās! Men cannot be united,

as long as there is jäti and community.'

Kabir also expressed similar sentiments.

'Don't ask a sadhu his jāti, ask about his wisdom.

Learn the value of the sword, don't pay attention to the scabbard.'

No Sant gave any importance to jāti. Nāmdev also said.

'I came to your door laughing and playing,

Practicing devotion "Nāmdev" was lifted up.

My birth was in a low jāti,

what does it matter if I was born a calico printer?' (Ram 1986, pp. 72-73)

Jagjivan Ram pointed out that the Sants had argued against discrimination based on religion. The term he used for "respecting all religions" (sarva dharma sambhava) had been coined by Gandhi, showing Jagjivan Ram's debt to Gandhian thought. However, Jagjivan Ram also pointed to a lack at the heart of formal religions, as he spoke about how there was "hollowness" (khoklepan) at their heart, but that the hollowness found in Islam and Hinduism was not found in Ravidās's teachings:

Ravidās also couldn't keep silent about respecting all religions,

or their hollowness.

‘O Ravidās! He who is my Ram,

He is also Rehman.

The Kāba and Kāśī, know this about them, they are both the same.'

And also:

'There is nothing distasteful in a Mosque, and nothing lovely in a temple.

Neither Allah nor Ram dwells in either, says Ravidās the Chamar.'

In an era when the importance of recognizing Hindu-Muslim unity was not recognized he [Ravidās] also revealed his humanitarian character.

‘Be a friend to Muslims, have affection for Hindus. 
O Ravidās! The light of Ram shines in all, all our friends.'

'Both paths are based on practice,

this is the strange drama the Creator established.

Hindus and Turks are one and the same,

brother! Ravidās declares this truth.'

'O Ravidās! There is no difference!

Between gold and a golden bracelet,

Just as there is no difference between Hindus and Turks.'

Jagjivan Ram then continued and said that "Ravidās believed in the religious tradition which had been developed by the original inhabitants of this land before the arising of Vedic religion and which contained truths which, when the Aryans encountered them, led to them creating their six philosophies and Upanishads." (Ram 1986, p. 74).

Finally, he cited one of Ravidās's most well-known verses, which was found in the Sikh sacred text the Adi Granth and in manuscripts from Rajasthan and UP and in print editions from around 1900 onwards. The version Jagjivan Ram cited is not exactly the same as any that I have seen in any print edition of Ravidās's works but is substantially the same as the version found in the Adi Granth. This verse had become central to the followers of Ravidās in the twentieth century as the key vision in Ravidās's works of the social, as well as a spiritual, revolutionary message taught by Ravidās. My translation of this passage is as follows:

The practice of the original inhabitants of here [India] was based on unbiased egalitarianism. The Sants were the fosterers of that tradition. They wanted to re-establish the religion and society which had been current in this land before the arrival of the Aryans. It was because of this that Ravidās proclaimed.

'Now I have found a home in my true homeland.

O brothers! There is always peace in that land.

That town is called "The Sorrowless City"!

There is no care or anxiety there.

No levies, no taxes, no duties.

No fear of failure or dread of loss.

The sovereignty there is fixed and stable.

None are second or third, all are as one.

It is forever flourishing and eternally renowned.

The dwellers in that town are always wealthy.

They wander around wherever they please.

None stop them from entering any of the palaces there.

Ravidās, the liberated Chamar says,

Whoever is my fellow citizen of that city,

They are my friend'. (Ram 1986, p. 74)

This verse contains a reference to a city called, begumpura, which became a kind of motto, or slogan, for the ideal that was hoped could be attained by the followers of Ravidās. The Hindi word begumpura could be understood as meaning different things depending on whether the word begum was taken to mean either "queen" or "sorrowless". Due to this, the city can be imagined as being called "The Sorrowless City" or "The Queen's City", or perhaps it could simply be understood as meaning "The city free from suffering". During the twentieth century, this verse came to be seen over time as representing Ravidās's ideal for how society should be structured. The key features read as being implicit in this verse were the creation of a society with no discrimination against anybody, with economic stability and good fortune and with the freedom for even a "liberated" Chamar to enter the public spaces in the world. This imagery, it should also be noted, was also found in Śiv Nārāyaṇ's vision of the "Land 
of the Sants" (sant des) and was a common image in Sant teachings. Due to this, it would have been familiar to Dalits from diverse communities as a commonly held vision for the possibility of, not just spiritual, but actual, liberation in this life.

Jagjivan Ram's conclusion was that the depressed classes (dalit samudāy) were now searching for their identity in contemporary India. Furthermore, in their search for humanitarian values and egalitarian traditions, it was essential for them to first explore their own history-a history that had been effaced and distorted by conquerors. He concluded as follows:

[I]n the lines of history written by the conquerors our history can also be seen, and even in the texts which advocate the caste system, such as Manusmriti, the rebellion against the system can be seen as a proof of the indomitable spirit of its opponents. (Ram 1986, p. 74)

The Sant tradition, he concluded, was a witness to the struggle of the countless masses who had been deprived of their human rights as embodiments of the divine. From amongst all the Sants, Ravidās also stood out as having been a shining pillar of light in their tradition that stood for the following:

$[\mathrm{H}]$ armony, peace, critical intellect, stability, resistance, unwaveringness, humanity, equality, and the living presence of the gem of the divine dwelling within humanity (Ram 1986, p. 74)

Jagjivan Ram's essay from 1986 presented the clearest picture of any of Jagjivan Ram's writings about how his vision of Ravidās's thought related to his vision of the world. It also, in almost every way, aligns with the teachings that I suggest could be found to have influenced Jagjivan Ram through his family's Śiv Nārāyaṇī background, but now focused on Ravidās, rather than Śiv Nārāyaṇ, as a symbol for how liberation was possible in life, in both the spiritual and mundane realms of the world itself.

\section{Conclusions: Jagjivan Ram as a Ravidāsī Politician}

In this paper, I have considered the relationship between peace, politics, and religion in Jagivan Ram's life. His life presents an important example of how religion and politics can contribute to peaceful approaches to conflict resolution. Confronted by the problems inherent in being Dalit in the twentieth century, a lack of critical power in society, he adopted non-confrontational strategies that avoided any sense of being "exclusive accounts of the nature of reality" (Kurtz 1995, p. 238). Instead, he argued that his own community's spiritual and religious teachings were distinct from Hinduism, as imagined by supporters of Hindutva. In his writings in Hindi, he spoke of a continuity between Ravidās's teachings and those of Hinduism as a broad and diverse religious tradition. All of this then formed the basis for his political struggles for liberation for not just Dalits but all economically deprived people in India.

In order to understand the relationship between religion and politics in the life of Jagiivan Ram, it is essential to consider the particular circumstances of his religious background growing up in a Siv Nārāyaṇi family. This is because the characteristics of the Śiv Nārāyaṇi movement as a religious and social reform movement also shaped Jagjivan Ram's political career.

Seen from this perspective, his actions were both religious and political. This led him to emphasize the importance of spirituality in life as linked to economic and social development for all including the depressed classes. It also led to his patronage of the Ravidāsī community through its sacred sites, festivals, sacred literature, and places of pilgrimage, as all were central to what he saw as the foundations of religious and political life. When considering the relationship between religion and politics in India today, it is essential to acknowledge how the immense diversity of religious cultures in India has contributed to its current political life.

My conclusion is that to understand political leaders such as Jagivan Ram, it is essential to acknowledge the diversity present within Hindu traditions and explore how a nuanced approach must be taken to unpack the forms of Hinduism espoused by leaders such as Jagjivan Ram. If this is not done, there is a danger that views based on Hindutva ideologies, which reject cultural diversity, may result in a negative impression of the relationship between the Hindu religion and politics in India. Perceptions 
of Jagjivan Ram as essentially a secular Dalit leader or a Hindu Dalit who supported Hindutva are both misleading. Jagjivan Ram's life and politics were shaped by his Dalit spiritual heritage and led to him becoming a champion for spiritual and political rights for all depressed classes and all Dalits.

Funding: This research received no specific external funding but was undertaken as a part of my regular research activities as an academic at the Australian National University.

Acknowledgments: I would like to express my gratitude to all the members of the Ravidāsī community and other communities who helped me learn about Ravidās and Dalit struggles for liberation and Amarjit Singh for his insights into the tradition and for introducing me to the Punjab Research Group in the UK. I would also like to express my gratitude to the late Professor Shukdeo Singh of BHU, Ramlakhan and the Sants I met at the Rajghat Ravidās temple. In addition, I would like to acknowledge my teachers including the late Krishna Mohan Singh of Harish Chandra Teaching Training College Varanasi, Ramdas Gupta, Rupert Snell and Simon Weightman of the School of Oriental and African Studies London University and Winand Callewaert of the University of Leuven. Finally, I would like to thank Jeffrey Haynes of the London Metropolitan University for his longstanding dedication to supporting scholarship on the relationship between religion and politics.

Conflicts of Interest: The author declares no conflict of interest.

\section{References}

Appleby, R. Scott. 2006. Building sustainable peace: The roles of local and transnational religious actors. Paper presented at the Conference on New Religious Pluralism in World Politics, Georgetown University, Washington, DC, USA, March 17.

Bellwinkel-Schempp, Maren. 2007. From Bhakti to Buddhism: Ravidās and Ambedkar. Economic and Political Weekly 42: 2177-83. Available online: www.jstor.org/stable/4419688 (accessed on 14 February 2020).

Beltz, Johannes. 2005. Mahar, Buddhist and Dalit: Religious Conversion and Socio-Political Emancipation. New Delhi: Manohar.

Callewaert, Winand. 1996. Śrī Guru Granth Sāhib, Vol 1. Delhi: Motilal Banarsidass.

Caturvedī, Paraśurām. 1972. Uttarī bhārat kī Sant-Paramparā. Ilāhābād: Bhartī Bhaṇạār.

Chaturvedi, Triloki Nath. 2005. 'Babu Jagjivan Ram: A Great Visionary. In Babu Jagjivan Ram in Parliament, a Commemorative Volume. Delhi: Lok Sabha Secretariat, pp. 39-58.

Dayāl, Harmohan. 2006. Varṇa vyavasthā aur kurīl vamś. In Upekṣit Samudayom kāa ātma itihās. Edited by Badrī Nārāyaṇ, Vị̣nu Mahāpatra and Anant Rām Miśrā. New Delhi: Vāṇī Prakaśan, pp. 203-84.

Grierson, George Abraham. 1918. The Siva Narayanis. The Journal of the Royal Asiatic Society of Great Britain and Ireland. pp. 114-17. Available online: https://www-jstor-org.virtual.anu.edu.au/stable/25209350 (accessed on 12 February 2020).

Jaffrelot, Christophe. 2003. India's Silent Revolution: The Rise of the Lower Castes in North India. London: C. Hurst \& Co. Publishers.

Kumar, Meira. 2005. My Father's Childhood. In Babu Jagjivan Ram in Parliament a Commemorative Volume. New Delhi: Lok Sabha Secretariat, pp. 34-38.

Kumar, Dhruv. 2013. Bihār Śatabdī Ke 100 Nāyak. Patna: Prabhāt Prakāśan.

Kurīl, Rāmcaran. 1941. Bhagvān Ravidās kī Satya Kathā. Kānpur: Kṛ̣ṇa Press.

Kurtz, Lester Ray. 1995. Gods in the Global Village. Pine Forge: Sage.

Maurya, Om Prakash. 2010. Babu Jagjivan Ram. Translated by Rupali Kishore. New Delhi: Publications Division Ministry of Information \& Broadcasting.

Mendelsohn, Oliver, and Marika Vicziany. 1998. The Untouchables. Cambridge: Cambridge University Press.

Nath, Trilok. 1987. Politics of the Depressed Classes. Delhi: Deputy Publications.

Omvedt, Gail. 2008. Seeking Begumpura: The Social Vision of Anticaste Intellectuals. New Delhi: Navayana Publishing. Pandey, Sangamlal. 1965. Existence, Devotion and Freedom: The Philosophy of Ravidāsa. Allahabad: Darshan Peeth. Paswan, Sanjay, and Pramanshi Jaideva, eds. 2004. Jagjivan Ram: Champion of Dalits. In Encyclopaedia of Dalits in India: Leaders. Delhi: Kalpaz Publications, vol. 4, pp. 77-127.

Patel, Hitendra K. 2017. Aspects of Mobilizations of Dalits in Bihar (1913-1952). Contemporary Voice of Dalit 9: 63-72. [CrossRef]

Ram, Jagjivan. 1980. Caste Challenge in India. New Delhi: Vision Books.

Ram, Jagjivan. 1986. īśvar ke aṃśdharoṃ kī asmitā ke pratīk guru ravidās. Ravidās 1: 70-74. 
Ram, Jagjivan. 2005. His Select Speeches in Parliament. In Babu Jagjivan Ram in Parliament a Commemorative Volume. New Delhi: Lok Sabha Secretariat, pp. 85-564.

Ram, Indrani Jagjivan. 2010. Milestones: A Memoir. New Delhi: Penguin.

Rāmlakhan. 1986a. Sant Ravidās aur unkā smārak. Ravidās 1: 65-69.

Rāmlakhan. 1986b. Guru Ravidās: Mandir, Kalpanā, Nirmān. Vārāṇasī: Ravidās Smārak Sosaițī.

Sagar. 2019. Why the DDA May Not Have a Legitimate Claim on a Part of Tughlaqabad's Ravidās Temple Land.

The Caravan. September 28. Available online: https://caravanmagazine.in/caste/why-the-dda-may-not-havea-legitimate-claim-on-a-part-of-tughlaqabads-Ravidas-temple-land (accessed on 10 February 2020).

Saran, Sant. 2017. Bābū Jagjī̄oan Rām aur Dalit Andolan. Naī Dillī: Vāṇī Prakāśan.

Śāstri, Rāmānand, and Virendra Pāṇdey. 1956. Sant Ravidās aur Unkā Kāoya. Lakhnau: Navbhārat Pres.

Savarkar, Vinayak Damodar. 1923. Essentials of Hindutva. Bombay: Veer Savarkar Prakashan.

Singh, Nau Nihal. 1977. Jagjivan Ram: Symbol of Social Change. Delhi: Sundeep Prakashan.

Tulsīdās. 1968. Śrī Rāmcaritmānas: With Hindi Text and English Translation. Gorakhpur: Gita Press.

Wilson, Horace Hayman. 1861. Siva Narayanis. In Sketch of the Religious Sects of the Hindus. London: Trubner and Company, pp. 358-59.

Zelliot, Eleanor, and Rohini Mokashi-Punekar, eds. 2005. Untouchable Saints: An Indian Phenomenon. New Delhi: Manohar.

(C) 2020 by the author. Licensee MDPI, Basel, Switzerland. This article is an open access article distributed under the terms and conditions of the Creative Commons Attribution (CC BY) license (http://creativecommons.org/licenses/by/4.0/). 